\title{
Narrative, Interpretation and the Popular Song
}

\author{
Keith Negus
}

FINAL VERSION submitted to Musical Quarterly February 2012 (prior to editing for publication). This text includes a minor amendment to acknowledge the passing of Walter Becker.

For the published version go here - https://academic.oup.com/mq/article-abstract/95/23/368/1009964? redirectedFrom=fulltext

The text includes lyrics from

\section{Kid Charlemagne}

Words and Music by Walter Becker and Donald Fagen

Copyright (C) 1976 UNIVERSAL MUSIC CORP.

Copyright Renewed.

All Rights Reserved. Used by Permission. 


\section{Narrative, Interpretation and the Popular Song}

The value of narratives in human understanding of the world is widely recognized. The importance of narrative is apparent in varieties of everyday storytelling as well is in written fiction, drama, spectacle and ritual, visual art and film, architecture, legal proceedings, scientific reports and political theory, to provide a only partial list indicative of the range. Yet, the popular song - one of the most pervasive narrative forms that people encounter in their daily lives - has been almost entirely ignored in the vast literature on narrative. ${ }^{1}$ Whilst narratological methods have often featured in the interpretation of western art music ${ }^{2}$ and film music ${ }^{3}$, and although literary approaches to lyrics have sometimes emphasized a poetics of storytelling ${ }^{4}$, theories of narrative have rarely been foregrounded in the study of popular songs. ${ }^{5}$

In this article I will focus on narrative to explore practices of interpretation in both scholarship and everyday discussion about popular songs. I will emphasize the intersubjective interpretation of song meanings and advocate an "intercontextual" approach to the understanding of song narratives, drawing from research which emphasizes how our knowledge of the world is cumulative and always in a process of becoming through time. Overall, argue for a musicological hermeneutics of the intersubjective production of value, belief and judgment. In developing this theme, the structure of this essay journeys from textuality through intertextuality towards intercontextuality. I will illustrate how popular songs participate in the wider cultural dialogues through which historical understanding is narrated, and explore how songs connect with more personal expressions of self and individual identity.

I begin with a sympathetic critique of David Nicholls's sustained attempt to begin addressing theses issues in an essay that signals its intent in the title - "Narrative Theory as an Analytical Tool in the Study of Popular Music Texts." ${ }^{\prime 6}$ I will diverge from Nicholls's analytical method by suggesting that the application of narrative theory to popular music must inevitably and fruitfully move beyond the world of the text and allied media to a much wider universe. I shall briefly summarize his approach as I move towards a critique and outwards from the text.

Nicholls starts with what he calls a "control level", level 1, where "there is no story per se in the lyrics, and as a consequence there is no element of narrative discourse in the musical setting." "At level 2 are songs with lyrics that include elements of narrative discourse that are not supported or reflected in a "neutral" musical setting. In contrast, level 3 refers to songs structured by a musical setting supporting the lyrical narratives. At level 4, lyrics and music are operating relatively independently and in a dynamic interactive manner to produce narrative meaning. Level 5 is characterized by a complex narrative conveyed through music, lyrics, visual imagery, along with accompanying prose and packaging.

Nicholls illustrates his typology by citing a range of songs, although in varying levels of detail. He fleetingly mentions The Beatles" "I Want To Hold Your Hand" and "Relax" by Frankie Goes to Hollywood as examples of level 1 non-narrative songs, and passes rapidly through level 2, offering only The Human League's "Don't You Want Me", which, despite clear narrative tensions and shifts between the lyrical viewpoints of the two protagonists of the duet, contains a "musical setting - in its unvarying melody and accompaniment textures - [that] resolutely resists any attempt at reflecting that narrative shift." 8 At level 3 he analyses Kate Bush's "Wuthering Heights" to identify how formal properties such as "an unexpected harmonic shift" and "harmonically unstable verses" support the narrative and "reflect the restless wandering of Cathy's spirit"9 - a clear assumption about the relationship between formal musical characteristics and extra-musical meaning, plausibly integrating lyrical interpretation with a narratological approach drawn from the study of western art music, also demonstrating how songs can change tense. 
At level 4 the analysis is more extensive and Nicholls explores how "instrumentation and timbre rather than melody and harmony" 10 are crucial to the narrative dynamics and semantics of Buggles" "Video Killed the Radio Star". Eventually he arrives at his fifth and highest level where "a complex narrative discourse is rendered through multiple media, including lyrics, music, prose, and art work." ${ }^{11}$ At level 5 he provides detailed analysis of The Lamb Lies Down on Broadway by Genesis and The Who's Quadrophenia - albums from a period (1973-74) when musicians were aspiring to be taken seriously by producing conceptual musical statements and when critics used the phrase "progressive rock" to distance such works from the stand-alone pop single (the idea of progress through increasing musical complexity is implicit in this typology). ${ }^{12}$

I do not dispute the intricacy of the tales that are told on these albums and their supporting prose and imagery (and in similar concept albums created during this period). Nicholls's analysis of the construction of narrative through text and paratext in progressive rock is insightful and convincing. What I find contentious is the dismissal of three minutes of pop romance at level 1 on the assumption that meaning resides in and arises out of a composite of tangible, easily identifiable and directly related "texts" - song lyrics, musical structures, liner notes, art work and the self-consciously conceptual artistic statements made by musicians. My challenge, and the point I wish to begin arguing for, is that there are other equally complex narrative meanings that are emergent in and articulated to many single pop songs, due to their embedding in a broader social and cultural context. In suggesting that Nicholls's approach is unnecessarily limited by its focus on musical text and identifiable supporting paratexts, I take a cue from Lawrence Kramer's argument that narrative cannot provide a means of "illuminating musical structure and musical unity" because the very "fractious and disorderly" character of narrative disrupts the stability of a text and points outwards at the real drama of performative actions (rather than the perceived drama of the music), towards the "social and cultural" tensions of the human world. ${ }^{13}$ Narrative ineluctably leads from the text to the historical circumstances through which the meaning of texts are mediated, interpreted and contested.

\section{II}

Songs do not convey narrative meanings alone as texts nor only in relation to supporting conceptual package. Songs exist in relation to other songs. The practice of songwriting and acts of interpretation are embedded within grids of intertextuality. Popular songwriters may explicitly or unconsciously draw their inspiration from other songs and sometimes unambiguously, or often obliquely, will reference, acknowledge, celebrate or comment upon these other songs. ${ }^{14}$ Even if the inspiration is implicit or unacknowledged, songs are heard alongside and in relation to other songs (by songwriter and listener alike). This is integral to how they narrate the world to us. I will substantiate and develop this point further by returning to Nicholls's example of "I Want To Hold Your Hand" - a song he describes in these terms:

The lyrics of the song paint a typically static romantic cameo, in which the protagonist expresses his feelings directly to the antagonist. Although there are slight changes of perspective in the exhortations of verse 2 and the more reflective stance of the middle 8 (accompanied in the latter case by a new melodic and harmonic setting), the text merely amplifies the statements already made by the protagonist, rather than suggesting any actual narrative discourse. ${ }^{15}$

Nicholls's claim can be contrasted with a perspective offered by Barbara Bradby in an article in which she analyses the profound influence on the Beatles of late 1950s and early 1960s girl groups. The Beatles were open in acknowledging their love of girl group music. They performed and recorded cover versions, toured with girl groups and the influence is evident in their lyric 
writing (offering different viewpoints and dialogue), song structures, harmonic sequences and use of voices (Lennon's and McCartney's unison singing and the 3 part harmony and vocal exchanges between Lennon, McCartney and Harrison). Hence, the song "I Want To Hold Your Hand" - in terms of songwriting performance practice and contextually - arises within a set of musical and cultural chains that cannot be decoupled from the text if seeking to understand the narrative meaning of the song. Indeed, Bradby suggests that girl groups established a "discourse to which the Beatles had to respond."16

Bradby pinpoints a contrast between the more passive plea in the lyrics for "you" to "let me be your man/ hold your hand" with that of an "opening narrative device, 'Now I'll tell you...' and the semi-narrative "When I touch you'". ${ }^{17}$ Bradby hears and reads unfolding narrative and semi-narrative features in the lyrics. These in turn are part of a broader narrative whereby the Beatles were offering a reciprocation of the girl group desire for "you" to love "me". Girl group songs had typically presented a singer talking about a boy in conversation with peers and chorus. The Beatles engaged in dialogue with this theme, mediating girl talk to the male world, most famously in "She Loves You" with its lyric of "she told me what to say". Bradby argues that "I Want To Hold Your Hand" presents a more tentative form of desire than the conventional male plea of "I want you", drawing directly from the Chantels" "Maybe", a song containing a plea for romantic holding hands as a route towards mutual understanding. Through a nuanced linguistic analysis of address in the Beatles songs of this period Bradby goes on to argue that

The Beatles' declarations of love in their first few hit songs did not come out of the blue nor are they simply a direct descendant of a line of male, or even boy-group, discourse. They are a response to, and in dialogue with, the voicing in girl talk by the Shirelles of the ubiquitous female request for men to tell women that they love them. ${ }^{18}$

Bradby's research challenges Nicholls's basic assumption: there is a narrative in the lyrics, the movement is not "static" as he suggests. Furthermore, the narrative acquires a sense of urgency through the way that the song establishes an intertextual and social dialogue with girl group discourse. It's an ongoing story about male/ female or boy/ girl romance mediated by the popular song.

But, the narrative is not just conveyed through the words. The lyrics of "I Want to Hold Your Hand" are heard through the "drama" of the music. Here I draw from Fred Everett Maus's observation that listeners often "follow" the meaning of instrumental music by drawing from a pool of knowledge that allows them to comprehend "commonplace human action in everyday life", personifying musical sounds that become regarded as characters, gestures and intentional actions. ${ }^{19}$ Evaluating the application of narrative theory to instrumental art music, Maus suggests that "music may often be closer to drama than to prose narrative, offering enactments of stories rather than story-telling in the most literal sense." 20 The drama of the music certainly contributes to the enactment of the scene in "I Want to Hold Your Hand" - providing an instrumental and rhythmic dynamic that may be heard as "a drama of interacting agents."

These musical elements have been discussed by a number of authors, with much comment devoted to the moment where the vocal melody rises an octave on the lyric "hand" as the chords move from Em, to an ambiguous B chord (various analysts and musicians have identified this chord as a B, Bm, B7 or B5) and then to $\mathrm{C}$. This is a pivotal instant of drama in the song's narrative. When he recalled writing the song with McCartney, Lennon referred to the inclusion of a particular chord (one that he did not specify) in this sequence, remarking that it "made the song". Walter Everett identifies it as a "deceptive" Em. ${ }^{22}$ Dominic Pedler disagrees and insists that Lennon was referring to the movement to the B chord, arguing that it is this that gives the passage "propulsion"23. Ian MacDonald also believed Lennon to be referring to the B chord and described the song as 
so dense with incident that McCartney's octave jump into falsetto at the end of the verse is pre-empted by another shock four bars earlier: a plunge from the home key of $\mathrm{G}$ major onto an unstable B minor ... It was exciting, unexpected, irreverent - and in practice made to seem natural by the beatific energy with which the group belted it out. ${ }^{24}$

Everett also writes of the "drama" created by the transitions between sections of the song and of how the song's textural, rhythmic and motivic factors contribute to the songs unfolding tale. ${ }^{25}$ Further drama is created through the vocals. Although Lennon takes the "lead", the two composers characteristically shift between singing in unison and singing in harmony, with McCartney varying his harmonizing between the first and second repeated "middle 8" section "And when I touch you". This section also contains the dramatic crescendo in which McCartney's vocal dynamically interacts with Lennon's in reaching up to a faltering falsetto on the repetition of "I can't hide"; a rising phrase that Bob Dylan famously, and perhaps not surprisingly given this euphoric moment, first heard as "I get high" and interpreted as signaling a drug enhanced peak. ${ }^{26}$

The rhythms also contribute to the excitement, accentuated by the handclaps. On the recording, even remastered, the handclaps sound rather thin, a little rhythmically irregular and vulnerable when compared with the later use of synthetically produced handclaps in recordings. This contributes to the sense of dramatic occasion, the handclap being a dynamic sonic presence and familiar as the most elementary way of participating in the performance of a song. The handclap is both material and symbolic, carrying associations of collective enactment, approval (applause), and a connection to childhood play. The handclaps in "I Want to Hold Your Hand" and other Beatles" songs provide a signifying link to nursery rhymes and memories of childhood innocence (these are pervasive themes and influences in Beatles songs). ${ }^{27}$

The above is offered as a challenge to Nicholls's characterization of "I Want to Hold Your Hand" as a song that "contains no meaningful narrative elements." 28 The lyrics are dynamic, rather than static words on a page, and can be interpreted as narrating an everyday encounter through the interplay of sung words and dynamic, dramatically interacting musical elements. The textual narrative arises from the poetics of the lyrics, the rhetoric of the vocal performance and dramaturgy of the music and rhythm.

Social and semiotic chains of narrative meaning connect the recording of "I Want to Hold Your Hand" (along with many other Beatles" songs from this period) to the songs of girl groups and the Beatles' male contemporaries. This is just one example of how songs continually enter narrative dialogues with other songs (whether or not it is conscious or intentional on the part of the songwriter). The popular song, in form, practice and character, is never reference free; no song can be totally "original" in the sense of having no precursors. Whether anticipated by its composer or interpreted by its listener, the song will signal, acknowledge, and pay some form of homage to its sources and inspiration.

"I Want to Hold Your Hand" is integral to a broader narrative that articulates the tensions and transformations in romantic relations between boys and girls, young women and men. The song arises out of, is embedded within and is also an intervention into the stories through which human relationships are mediated and comprehended. It is an example of how a song's meaning is simultaneously contextual and social. Or, as I shall now argue, song meanings are intersubjective and intercontextual - the interpreting author is part of these dialogues. 
It has become something of a commonplace for anthropologists, sociological researchers and ethnomusicologists to reflexively locate themselves in their work, particularly during introductions to research monographs. Such a strategy is rare in musicology, and can usually be found in writings in which the musicologist positions her or himself sociologically. ${ }^{29}$ It is uncommon for musicologists to expose their aesthetic preferences, musical skills, social background, educational experiences or even the manner in which they listened to the recordings referred to in their work. Even self-defined "critical musicologists" - attuned to the theoretical and pragmatic possibilities for varied interpretation, aware that songs are mediated technologically, socially and commercially - offer little by way of the situational context that has informed their choice of repertoire, listening strategy and analytical approach. To pursue this I want to take a critical route through three perspectives on the question of individual reception and authoritative interpretation.

I start with the concept of "subject position", an idea advanced in musicology by Eric Clarke and Nicola Dibben when seeking to connect formal musicological analysis and critical interpretation to the understandings of listeners. Drawing the term "subject position" from its development in Althusserian Marxism and psychoanalysis (to explain the limiting and oppressive workings of dominant social structures and ideologies) and the way it was incorporated into film studies, Clarke argues that the concept of subject position allows for an understanding of how a text (a film or music, for example) is such that it "demands", "solicits" and "limits" the perceptions of an audience member. ${ }^{30}$

Clarke uses this concept when comparing the recorded performance of "Magdalena" by Frank Zappa with that of PJ Harvey's "Taut." Dibben deploys the idea in an analysis of the songs and imagery associated with Pulp's This is Hardcore and, through this, in arguments about the impact of Jarvis Cocker's songs. Both writers use the notion of subject position to claim a clear link between listeners' comprehension and their analytical interpretation of "musical material" arguing that the "features of the musical materials specify the subjectposition of the song.", 31

Clarke describes in detail the contrasting gendered characteristics and connotations of the sonic, vocal and lyrical qualities of the Zappa and Harvey tracks and asserts that "subjectmatter and subject-position interact in a compelling manner." ${ }^{, 32}$ Using the same concept, and citing its use by Clarke, Dibben presents an analysis of how Pulp (or specifically Jarvis Cocker as songwriter and singer), create a critical, if ambiguous, perspective on masculinity and pornography through visual imagery, song lyrics, use of voice, lead guitar motifs and instrumental timbres. As an analysis of how a highly idiosyncratic musical identity containing "a bleak and ironic view of the single male" 33 has been produced through an album package Dibben's analysis is insightful and convincing. However, to this textual analysis Dibben adds theory drawn from psychoanalysis and cinema spectatorship, arguing that the "subject matter" of the album (lyrics as semantic statements, guitars as sexual signifiers, images alluding to the conventions of a male gaze in heterosexual pornography) is such that it "solicits" and "positions" the listener into a "place" from which their understanding of the music and imagery ineluctably corresponds with the interpretation of the musicological analyst. In the case of Pulp, this "subject position" is assumed to incorporate a cultural critique of various assumptions about the masculine response to pornography.

Clarke and Dibben offer astute musicological insights and plausible interpretations of the songs of Zappa, Harvey and Pulp, respectively. But, they both take large leaps outwards when claiming that their musicological hermeneutic analysis has identified the content that positions "subjects", assuming that their interpretations are comprehensive enough to contain the meanings that all listeners will have to contend with. The claim that analysis has revealed a broader subject position is asserted rather than demonstrated with any evidence of what other 
members of the audience may think about these songs. The claim to have identified the "position" of a unified and rather abstracted "subject" (all those listening to the recordings?) is based on little more than interpretation of the "musical materials."

A different approach is offered by Tia DeNora when challenging the "concealed authoritarianism" of what she calls "armchair hermeneutics", arguing that it ignores the way people "use" music in their lives. ${ }^{34}$ Indeed, Clarke subsequently modified the strength of his argument in response to such an objection, claiming that a "subject position" approach can "define an area of possibilities within which different empirical individuals may take up their own particular positions." ${ }^{35}$ However, DeNora's response to such a caveat would seem to be that this is still speculative unless the "empirical individuals" are studied. Through her research, DeNora has repeatedly attempted to show how people use music in ways and in "positions" that are not so easily predicted. Instead of starting with the text or "musical materials" (the song, composition or track) she privileges the circumstances. For example, she writes of how people turn to music when dealing with difficult moments of tragedy or loss in their lives - one of DeNora's respondents listened to a Brahms concerto when recalling aspects of her relationship with her father after his death; the novelist Anthony Burgess listened to Beethoven when working out a plot for a novel; a track carefully constructed in a studio by George Michael was incorporated into the ritual of selecting and purchasing clothes. ${ }^{36}$

If Clarke and Dibben are concerned with the determining character of songs and music the way texts influence values, knowledge and aesthetic understanding - DeNora instead finds reflexively aware, freely active citizens: "Listeners are by no means simply 'affected' by music but are, rather, active in constructing their 'passivity' to music." ${ }^{37}$ If Clarke and Dibben seek to highlight the significant impact of a subtle guitar timbre or a quirkily vocalized turn of phrase, DeNora downplays the musical qualities of songs or concertos, inadvertently perhaps, allowing them to become little more than a secondary means towards some more significant sociological end. This is because she wants to move the argument "to a far more general notion of how different types of musical materials may afford different actors different things at different times." ${ }^{38}$ Yet, it then seems as if any type of music can stand in as a resource or device in a whole range of situations, and this is how it acquires its sociological value. Music becomes a means for working through an emotional difficulty, physical task, habitual routine or intellectual problem. It appears to be no different to other "resources" that we might have at our disposal (such as drinking a glass of wine, walking through a forest, smoking a cigarette or swimming). There is something salutary in this sort of approach. After all, not everyone wants to spend inordinate amounts of time debating the meaning and influence of a lone cadence, poetic phrase or guitar riff. But for those of us who do, and for those of us who want to argue that it is important because there $i s$ a quite profound connection between the aesthetic qualities of a symphony or song and social life, then DeNora's approach comes close to breaking the connections by siding with the user's viewpoint.

An attempt to retain the link to the musical text and to acknowledge De Nora's emphasis on the varied uses of music by subjects, has been offered by Chris Kennett when proposing that the meaning of any recording is variable and indelibly mediated by "the temporal, demographic, attentive, local and task-related particulars of the listening situation. ... [These] ... conspire to dilute the analytical meanings of the well-parsed text to such an extent that the absolute sound recording ceases to exist as an object of analysis." ${ }^{39}$ Ironically critiquing Richard Middleton's wish to avoid "monological" interpretations of songs (Kennett also targets analysis by Allan Moore and Philip Tagg) he argues that "personal listening" is all that scholars can legitimately offer: "One interpretation of a recording is just that - one person's non-normative way of understanding a musical text, arrived at through several immersive, concentrated listenings (through hi-fi speakers or headphones, without interruption or diversion) to the recording at home, or in one's office - and nothing more absolute than that." 40 
Kennett initially supports this position with reference to observations of the musical preferences and listening strategies of visitors to a wine shop in which drum'n'bass is playing. ${ }^{41}$ He illustrates his case further through what he calls an "idioethnomusicology" of Herb Alpert's "Tijuana Taxi", heard as Leyton Orient Football team trot on to the pitch prior to games in East London, the musical content comprehended though this ritual. Contextualizing his interpretation of the song's meaning in relation to the unsophisticated tactics of the football team, and supporting this interpretation of the music with some highly personal details of about himself (including his class background, a disability, schooling, his parents, selective life experiences and obsessions, along with knowledge of sport and wine), Kennett seeks to illustrate in detail the formation of his "personal" musicological analysis. His overall point is that "the listener's demography or prior lived experience" will "change the very nature of the text." 42

The ironic catch in such an idio-autobiographical, obsessively existential analysis is that Kennett has arrived at such a meaning through constant social interactions - it is not quite as "personal" as he would claim. Kennett acknowledges that "the only people with any likelihood of sharing much of an overlap with my analysis of the song are fellow Orient fans." ${ }^{, 43}$ However, I would question his use of the term "sharing" here. As humans we can share in, and reach a broad consensus about the meaning, value and ethical or political significance of many texts, artifacts and practices, without necessarily sharing the same demography or prior lived experience (this is, after all, how an understanding of language is acquired). We may never have been to Leyton Orient Football Club, but we may empathize with this interpretation of "Tijuana Taxi." 44 Despite Clarke's claim that the "musical materials" can reveal the possible interpretations of subjects, I doubt whether an analysis that started with the musical materials of "Tijuana Taxi" would have led to Leyton Orient football ground in East London - which is, in many respects, Kennett's point.

If Clarke and Dibben avoid such variable interpretations by positing a subject position that corresponds to their analysis of selective musical materials, Kennett evades the way that many people can share a similar understanding of a song yet be different according to all manner of personal quirks and idiosyncrasies. ${ }^{45}$ If Kennett makes the conditions of listening (a wine shop or a football stadium) dominate his interpretation - "the listening experience becomes the text" office, in a car, at a football match? If Kennett's fandom and aesthetic choices are conspicuous due to their elevated presence, Dibben's and Clarke's preferences are conspicuous by their absence. I might infer that Dibben is a fan of Pulp, that Clarke is a fan of P J Harvey but not Frank Zappa, but neither make it part of their argument. This issue is not tangential or extraneous. Both Simon Frith and Ian Maxwell have argued, adding weight to Kennett's point, that the selection of music and musicians as objects of study and academic analysis is informed by tacit if often unacknowledged value judgments, personal preferences and passions. In Maxwell's terms it is the "curse of fandom" - a burden that poses problems and possibilities. ${ }^{47}$ At the core of these contrasting positions are questions about how musicology moves outwards from "the musical materials" or "text" to social circumstances, and acknowledges that such contexts are informed by personal as much as scholarly commitments to processes of interpretation.

One way of disrupting such movements, drawing from narratology, might be to make a distinction between the "point of view" presented to any listener through a text, and the way this may or may not construct a "subject position" as a set of sonic, social and semantic possibilities from which a self may "negotiate" that text. The term "point of view" refers to the vantage point from which the story is conveyed, described by H Porter Abbott as the "the lens through which we see characters and events in the narrative. Frequently, the narrator is our focalizer. Just as we hear her voice, we often see the action through her eyes"48 For example, in Lennon's and McCartney's folk style ballad "You've Got To Hide Your Love Away" the narrator of the song is worrying that he might have lost his love, and the listener hears an exchange between the 
narrator and the "clowns" that are telling him to hide his love: We hear the clowns ("Hey! You've got to hide your love away") from the point of view of the narrator. In the country blues inflected "You've Got A Friend In Me" the narrator sings from the point of view of the toy Woody addressing the child Andy in Toy Story 1. In later films in the Toy Story series the song is included, performed in different styles and arrangements, to represent the viewpoint of all Andy's toys. The song is also used in various ironic, intertextual and self-referential ways - for example, adding a degree of pathos to the narrative of Andy's ageing and eventual farewell to toys along with family home.

In considering the point of view, I do not need to assume that the track sung by John Lennon or the Toy Story film song constructs a position for listeners, and I can acknowledge that the songs - if rendered by other performers on albums or in concert - may offer potentials for alternative interpretations. I might hear the narrator of the Beatles' song as telling me, a listener, to hide my love away (the performance, instrumentation, arrangement or vocal intonation along with my casual distracted attention whilst queuing for a drink may lead to such an interpretation). Or I might hear it as an interior dialogue, the narrator talking to himself. Taken out of its location within the films, "You've Got A Friend In Me" may be used to convey a sense of friendship between adults, or between children and an animal pet, rather than a toy and a boy. The song's ambiguity allows for these different interpretations. Indeed, the craft of songwriter Randy Newman, skilled in the art of irony and versed in screen music, and the song's use across three films by animation company Pixar, adroit at creating life histories and emotions from animated images, is a reminder of the poetic possibilities of ambiguity. In a book first published in 1930s, William Empson explored the poetic and interpretative value of ambiguity, referring to "any verbal nuance, however slight which gives room for alternative reactions to the same piece of language" whereby "alternative views might be taken without sheer misreading". ${ }^{9}$ Empson argued that "the machinations of ambiguity are among the very roots of poetry" Umberto Eco has also stressed, there are "limits of the act of interpretation." ${ }^{, 51}$ It is misleading to declare that all we can offer is an endless plurality of personal listening. "You've Got A Friend In $\mathrm{Me}$ " is not a song conveying dialogues from the French Revolution of 1789. It is not a song in support of the destruction of toys or the culling of badgers. It is not about moonlight on a stormy sea, nor does it refer to the tensions between Romulans and Vulcans. It might perhaps be possible to explain the circumstances within which an individual may interpret the song in one of these ways - the internet provides plenty of examples of misheard lyrics and eccentric understandings of songs. But, these endure as ironic anecdotal oddities rather than convincing contributions to discussions about songs and their social resonances. ${ }^{52}$ When considering the multiple interpretations of personal listeners we cannot evade questions of plausibility, "misreading" and "overinterpretation.,"53

In the remainder of this article I want to argue for the adoption of an intermediate position: an approach that is attuned to the limitations of both the authoritative, monological, objective, definitive or dominant interpretation and the pluralist, solipsistic, subjective, individual or personal perspective. I also want to argue for a series of related hermeneutic and analytical shifts; from position to process, from personal and subjective to inter-personal and inter-subjective, from the located and spatial context, to the historical and temporal intercontext. From metaphors of static places and locations to metaphors of movement and change - from interpretations that are fixed to locations (the clothes shop, the academic study, the football stadium) to interpretations that are changing, in process, moving through time. 
In developing my argument in this direction, I am drawing from Paul Ricoeur's wide-ranging philosophical investigations in which he stressed how self-understanding is realized through narratives that give order to the uncertainties and unknowns of temporal existence. We comprehend ourselves and the world we inhabit through the stories that we tell. ${ }^{54}$ Our narratives include the telling of our social encounters; hence Ricoeur's approach implies "that all communicative action must be hermeneutically grounded because it is always intersubjectively mediated." of self-identity while at the same time bridging the gap between self and other." ${ }^{, 56}$ Although his philosophical reflections were developed from detailed study of literary fiction and history, Ricoeur argued for an inclusive approach to narrative, imagination and history. He pointed to a "complementarity" and a "convergence of the different modes of narrative discourse" whereby "the intersubjective field of temporal experience" bridges and connects "the most 'fictional,' such as tales, romances, dramas, novels, and movies, to the most 'empirical,' including histories, biographies and autobiographies."

Ricoeur's hermeneutics is just one strand within a considerable body of writing that starts from Edmund Husserl's argument that any "objective" understanding of the world is "intersubjective." Whilst there are various debates in this literature, and different inflections to the term, in this essay I also draw on Nick Crossley's suggestion that a focus on intersubjectivity allows for a consideration of "the fabric of social becoming", a metaphor suggesting "a certain material basis, a corporeal inter twining." 58

Such a process of becoming is also implied in the related concept I want to introduce, that of "intercontextuality" as developed by David Bloome and his colleagues in studies of how classroom learning takes place cumulatively over time (days, weeks, months, years). Understandings produced in the present are the result of interactions that draw upon existing knowledge and memories, which in the process move constantly from individual to collective. The intercontextual accumulation of knowledge through time links events in such a way that "people react not only to immediately contiguous acts but also to acts separated in time and space and they may react to a set of acts." 59

I want to illustrate, explore and develop the value of this approach with reference to the song "Kid Charlemagne" which appeared as the opening track on Steely Dan's 1976 album The Royal Scam. In doing so, I want to tentatively retain a sense of "personal listening" as advocated by Kennett - not seeking to conceal myself in the interpretation of this song. But, I also wish to emphasize the intersubjective and intercontextual dynamics though which a shared understanding of the song is created - my understanding can never be unique but always realized in relation to the actions, values and views of other people. Due to this emphasis, I do not wish to present a privileged "text" as abstracted song lyric or musical examples on a page, and I want to convey a sense of how my understanding of this song has emerged cumulatively and intersubjectively. ${ }^{60}$ The music can be heard, and the band seen at various freely accessible YouTube sites. I hope that my overall argument stands, even for readers unfamiliar with the specific song.

Steely Dan was a vehicle for songwriters Donald Fagen and Walter Becker (who sadly passed away in 2017), playing keyboards and bass respectively, supported by a host of accomplished musicians. The band released albums between 1972 and 1980 and, following a long gap, from 2000 onwards. In a musicological analysis of their style Everett noted that although "nominally a rock band ... the group's melodic idiosyncrasies, busy rhythmic surface, and harmonic and voice-leading techniques are direct descendants of early modern jazz, making the corpus arguably the most tonally complex of any rock music with such broad popularity.",61 The lyrics to the songs show the influence of 1950s science fiction (notably A. E. van Vogt and Alfred Bester), along with ironists such as Thomas Berger, Philip Roth and Kurt Vonnegut. At 
the same time, the songs exhibit a knowing familiarity with and referencing of harmonic, verbal and structural tricks from the "Great American Songbook." 62 Of their approach to songs Fagen explained "we were after a theatrical effect, the friction produced by the mix of the music and the irony of the lyrics." ${ }^{63}$ The narrators are often deluded loners or dreamers, romantic male losers peering at life from the periphery. The influence of Bob Dylan is apparent, not only in lyrical tone but in Fagen's untrained, understated, dry, wry and slightly pinched nasal vocal delivery. Although the majority of songs are narrated in the first person, they are quite obviously delivered by characters, the songwriters operating at a knowing critical distance from "confessional" or autobiographical writing. ${ }^{64}$

When I first heard the track "Kid Charlemagne" I had no clear idea what the song was "about." I responded according to my immediate points of reference at the time. I heard a blend of disco-funk groove, insistent hissing hi-hat, and smooth bell-like resonant Fender Rhodes electronic piano mixed with the squelchy staccato tones of the clavinet (an unavoidable reference point being Stevie Wonder's influential clavinet driven "Superstition"). I recall vocal phrases leaping out and being intrigued by impressions of an unfolding tale of tension, anxiety and release that was in some way concerned with marginal or criminal activity from which a central protagonist wished to escape. I had only become familiar with Steely Dan a year or so prior to the release of this track and had not been following their recordings since their first album in 1972. I was not a "fan" at the time of first hearing this song (played to me by a neighborhood friend), but I was in the processes of becoming one, particularly through my engagement with the album The Royal Scam in which "Kid Charlemagne" is the opening song. My discussion here, and my decision to use the song in teaching - an experience from which I shall draw - is inevitably based on periods of intensive listening, reading about, discussion and reflection upon the song.

Just over 30 years after its first release, in 2007, I played the song to a class of predominantly British undergraduate music students (taking pathways in both popular and western art music) in a class in which we were exploring the different ways that songs tell stories. At the time I was not playing it with a view to later reflecting upon and writing up the experience and so I was initially disappointed that none of the 35 or so students (aged between 19 and 23) had previously heard the track. I played it once without providing any context or information. I asked if anyone would like to tell me what the song was about. I found no suggestions. No one felt confident enough to publicly volunteer an opinion based on one, decontextualized listen within the unequal, constrained circumstances of a teaching encounter.

I then provided the class with a preprepared lyric sheet on which I had made various notes relating to shifts of perspective and changes to vocal emphasis. The opening lines set the scene: "While the music played you worked by candle light, those San Francisco nights, you were the best in town. Just by chance you crossed the diamond with the pearl, you turned it on the world, that's when you turned the world around."

I was attempting to introduce the class to basic concepts from narrative theory and I noted that the song begins in the past tense with a narrator seeking to occupy a second-person point of view, or, more plausibly, telling the story as a first person seeking to imagine the second person's perspective; this becomes apparent with the line "did you feel like Jesus?" Any sense of optimism evaporates at the end of the second verse when the protagonists feels his "whole world fall apart and fade away." The third verse shifts from the past to the present tense and evokes a situation characterized by images of debt ("your patrons have all left you in the red"), death ("low rent friends are dead") and deception. The second-person "you" is still being addressed by a first-person "I", a detached commentator on events. The last verse remains in the present tense, but the point of view shifts; the narrator has quite clearly become an anxious participant ("clean this mess up else we'll all end up in jail"). Throughout the song the chorus returns with the "get along, get along Kid Charlemagne" refrain (more or less chanted, rhythmically in unison, the harmonies mixed down). Each time it acquires additional 
resonances, as the plot is progressed through the verses, from its first appearance which may be interpreted as a colloquial "get along with you", to its appearance after the final verse which may be heard as "get out of here." 65

Having circulated lightly notated lyrics, I played the recording through again. The second listen allowed for a discussion and, quite quickly, a debate that moved towards an interpretation of the song. There were various opinions about just what was being manufactured (the literal production of a blend of "diamonds" and "pearls" in the lyric was quickly

discounted). It was not long before the conversation reached a point where the class agreed that the song was about the production of illegal drugs. The students had quite clearly been drawing on their existing "intercontextual" knowledge of songs, references to drugs in popular culture and a range of related experiences and information.

When the class conversation reached this point I intervened more directly and explained how the lyrical narrative of "Kid Charlemagne" can be interpreted as making direct references to a period in the life of Owsley Stanley who manufactured and then supplied LSD to the counter culture during the 1960s. His identity is partially camouflaged in lyrics that evoke the name of ("Kid") Charlemagne - setting in play associations with a historical figure, Charles the Great. Stanley was feted as the first "underground" chemist to produce LSD during the 1960s, and reputed to have produced and supplied over a million doses. Contemporary connoisseurs of the drug praised its apparent purity; a quality alluded to in the song's lyrics. A further infamous incident has Stanley being arrested after his car ran out of gasoline. Whether or not this is apocryphal, the lyrics mention this ("is there gas in the car?"). Shortly after the album's release the rock critic Max Bell described the stance in the lyrics as "unromantic, precise and factual" arguing that the song doesn't convey "any mood other than ambivalence."

When I suggested that the drug in question was LSD and offered these background details of Owsley Stanley, I received a mixed reaction from the class. Some students were excited and intrigued by the narrative, whilst others were mildly shocked that the drug was portrayed from the perspective of a manufacturer and participant. There was some disagreement about whether the song might be interpreted as a morality tale in which the villain got his comeuppance, an endorsement of the drug or an ethically neutral and factual portrayal of the protagonists. Consistent with Bell's view of the song's ambivalence, such responses were also indicative of how changing attitudes towards and experiences of drugs among students have subsequently inflected interpretations of the song. John Markert's study of "drug lyrics in popular music" (drawing on interpretations of lyrics and opinion surveys) over a forty-year period suggests that whilst LSD tended to be uncritically celebrated in songs of the late 1960s. By the middle of the 1970s (when "Kid Charlemagne" was released) an uncertainty had crept in and this turned to more negative judgments and critical portrayals in the $1980 \mathrm{~s}^{67}$

Although lyrics will inevitably play an important part in discussion of the meaning of popular songs, the music and rhythms also aroused comment. The class included accomplished musicians, and without prompting, students remarked on the use of jazz chords and judged the effectiveness of certain chord sequences. "Kid Charlemagne" opens with a repeated C7\#9 chord before dropping to an unexpected Am, as if moving down into a song world we might not have anticipated. This is followed by what might be heard as a "predictable" Aeolian fall from Am through $\mathrm{G}$, then to $\mathrm{F}$ but this is undercut by a subsequent move to a $\mathrm{Bb} 7$ add6 before returning to the Am. ${ }^{68}$ Though the chords cannot necessarily be identified precisely on one or two listens, the disruption of this sequence (along with the opening) was heard as conveying a sense of unease and melodrama and was judged by the students as integral to the narrative. Some students observed how the drums were used in the song to convey urgency and desperation. Also singled out was an extended virtuoso guitar solo performed by Larry Carlton that forms a bridge between verses two and three; an instrumental interlude that allows for a segue from the narrator 
as detached observer to anxious participant, personifying the narrator's changed demeanor and point of view - from flowing melodic calm, through hesitation to anxiety.

I subsequently followed up the more or less spontaneous classroom conversation by researching exchanges about this song in various internet forums and by talking with other musical trained and non-trained music listeners. ${ }^{69}$ I have found comparable, yet often more intense and elaborated, exchanges about this song amongst fans, individuals usually more knowledgeable of the band than the students referred to in the above discussion and aware of Steely Dan's blend of musical characteristics, lyrical concerns, attention to details and idiosyncratic sensibility.

Steely Dan albums were constructed with an awareness of how their songs, composed for recordings, are listened to hundreds of times by fans. This awareness informed the insertion of musical and lyrical references to obscure jazz recordings, to novels, to real events and people, along with sonic and verbal quotes, puns and allusions. The meaning of songs and their lyrics is not acquired through one listen. It builds up from repeated listens. As I mentioned earlier, lyrics may be misunderstood or incomprehensible on a first listen. The listener might initially respond to the texture or grain of a particular voice, or to the words as non-semantic sounds or to prominent key words. Lyrics assume greater significance and accumulate meaning with repeated listening, and from discussions with other fans, and from reading commentaries, criticism and interviews. Fans of all genres, musicians and aspiring songwriters may copy lyrics into notebooks, or type them up (just as older composers copied out scores by hand), amending their versions as a result of repeated listening and conversations with others.

The interpretative activities of Steely Dan fans are evidenced in an "anecdotal survey" conducted by journalist Robert Toth. He provides an insight into the intensity with which fans listen to and follow up lyrical and musical references and illustrates the way fans think of their engagement with the songs as part of a "musical education". Toth's interviewees valued Steely Dan for their "irreverence and complexity", their "cynicism and humor" and "craftsmanship". Most fans developed a love of the band incrementally through an ongoing process rather than through one epiphanal moment (although epiphanies - "musical awakenings" - were recounted on some of the fan's trajectories). ${ }^{70}$ As with other studies of fans, Toth illustrates how musicians offer a point of identification - in this case for those who sense an affiliation to the wry, knowing "outsider" stance. ${ }^{71} \mathrm{He}$ also provides illuminating examples of the time and effort committed by devotees when interpreting the musical and lyrical reference points, entailing intersubjective dialogues with others and contributing to "a special vibe among Steely Dan fans." 72

During the class discussion I had to admit to students that I did not have answers to some of the specific questions that were raised about drugs and the counterculture. Having encountered the LSD manufacturer "Kid Charlemagne" it was but a short step to questions concerning other songs about LSD and to writings about the counterculture. The students were seeking to bring their own partial knowledge of history to bear on the interpretation of a song, and this was meeting with my own limited knowledge of songs and this period in history. For me it was a concrete everyday experience that illustrated how songs are both imaginative fictions and part of intersubjective dialogues about history. My immediate response was to find out more - to research further details about the counterculture, and songs about LSD and Owsley Stanley.

An obvious reference point is Sheila Whiteley's analysis of songs and the counterculture, in which she notes that while some songwriters (like novelists and poets) sought to directly evoke their experience of taking LSD, often informed by a mystical or metaphysical quest for philosophical enlightenment, far more followed a fad for creating psychedelic sounding records. The psychedelic aesthetic sought to emphasize a heightened awareness of the senses (represented through exaggerated use of echo and effects in sound production, and intensely bright timbres); a distorted sense of reality (sounds oscillating or hanging suspended 
before fading); the synaesthetic merging of the senses and the evocation of innocent, fairy tale or dream like states of consciousness, conveyed through surreal lyrics and the use of echo, reverb, dramatic and sudden edits, collages or abrupt changes of tempo or timbre. ${ }^{73}$

Any popular song that concerns the drug LSD will establish links to an identifiable body of songs. But, "Kid Charlemagne" is unusual because it narrates the activities of a very specific character actively making and supplying the drug. It does not attempt to evoke the drug experience, nor does it incorporate any form of psychedelic coding. Indeed, its jazz harmonies and voicing along with disco and funk elements offset any overt rock elements that might be associated with the electric guitar. Musically, a distance is created from the evocation of the LSD experience.

Lyrically, the activities of the central protagonist Owsley Stanley are narrated with a degree of distance from the experience of taking the drug and are consonant with how he has been portrayed in historical accounts of the period. In a book subtitled "LSD and the American dream" Jay Stevens devotes a chapter entitled "The Alchemist" to Stanley, claiming that Newsweek compared him to Henry Ford. He portrays Stanley as a talented, eccentric, intelligent man with many theories feeding a mission to "save the world by making the purest and cheapest and most abundant LSD possible" 74 . Stevens charts how a mixture of ideas circulating from chemistry, eastern mysticism and literary creativity fed a belief that "Owsley's career as an underground chemist was graced by divine approval"75 - in the words of the Steely Dan song he may well have "felt like Jesus". Martin Lee and Bruce Shlain, in a similar way, portray a man who, in the hippy district of Haight-Ashbury, was known as "the unofficial mayor of San Francisco" and who "cultivated an image as a wizard-alchemist whose intensions with LSD were priestly and magical"76. The backdrop to Stanley's activities was a sharp contrast between the will to change the world "for all" through collective political engagement with civil rights and anti war protest and the desire for "tuning in and dropping out" which offered the individual a solipsistic "promise of transcendence of that world",

The ironies, contradictions and absurdities are registered in three songs of the period. Stanley had been an audio engineer for the Grateful Dead and is credited with making a significant contribution to their live sound. In 1966 the Grateful Dead began performing a song with the title "Alice D Millionaire" (a play on words, that wryly cites the newspaper headline following Owsley's first arrest; "LSD Millionaire Arrested"). Musically a mid-paced folk-rock arrangement, the lyrics to the song address a "girl" (Alice), but there can be little doubt that the third person is Stanley, as the lyric narrates the moment when his world was falling apart and fading away, opening by evoking a protagonist living in a "world of trouble" and moving on to suggest that his secret is out, "the walls are closing in" and "the wheel of fortune has a flat tire" - another reference to the infamous car break down which facilitated Stanley's arrest.

This largely sympathetic or neutral account might be heard alongside Frank Zappa's sarcastic "Who Needs the Peace Corps?" which appeared on We're Only In It For the Money, an album that pastiched the cover of The Beatles Sgt Pepper's Lonely Hearts Club Band and that ridiculed hippies, the counterculture and 'summer of love". An arch and fussy musical arrangement, incorporating references to r'n'b along with modernist art music, "Who Needs the Peace Corps?" opens with a naïve first person narrator declaring that he will "drop out" go to San Francisco, purchase "a wig and sleep on Owsley's floor" and continues to ridicule through images of "phony" stoned hippies and "psychedelic dungeons popping up on every street."

A further commentary is provided in the song "Mexico" recorded by Jefferson Airplane in 1970 and written by Grace Slick. Another typically mid-paced folk rock song, it opens with the words "Owsley and Charlie, twins of the trade", celebrating the impact of drugs on the poetic imagination and narrating attempts to stop the transport of marijuana from Mexico into the United States. Caricaturing a man only referred to as "Richard" who aspires to be king (almost unambiguously then US President Richard Nixon) it pays respect to drug suppliers and proclaims Owsley to be a "legend" for providing "righteous dope." 
Zappa's mockery, the Grateful Dead's melancholy, Grace Slick's homage and the docudrama of "Kid Charlemagne" all contribute to the cultural history of this period, mediating evaluations and commentaries on people and events, making a modest but not insignificant addition to an enduring series of (by no means consensual) narratives about the drug culture of San Francisco, its peculiarities and characters, its utopian dreams and instabilities, and its subsequent decline. "Kid Charlemagne" conveys a specific interpretation of history, provides a particular memory of events and offers a critical commentary on a protagonist who rapidly moves from being likened to "Jesus" to being "obsolete".

Historical knowledge and understanding of any period is acquired, accumulated and enstoried - narrated - through a panoply of cultural forms of which songs are an important part. "Kid Charlemagne" contributes to the conversations through which the past is documented and debated. As a song it is one cultural form playing a part in the mediation of historic events to music fans now and to future historians. The song remembers, re-tells and re-evaluates. It links together a particular series of events, experiences and moments in time, dramatizing these musically and lyrically. The meaning of "Kid Charlemagne" does not reside solely in its textual characteristics: the musical or textual "materials" of this song cannot manipulatively position us as "subjects." Equally, its meaning cannot be liberated by idiosyncratic social use or solipsistic personal listening strategy. "I Want to Hold Your Hand" or "Kid Charlemagne" - and any other popular song - is always part of an intersubjective, intercontextual conversation, during which interpretation is in progress, forever moving through the time - proffered, debated, adopted as plausible or discarded as improbable.

\section{V}

I have supported my argument in this article by drawing from discussion during teaching, exchanges on internet sites, dialogues amongst fans and talk about songs that I have participated in more informally, not because I seek to legitimate a fixed interpretation of "Kid

Charlemagne", but because I want to highlight the intersubjective, intercontextual and temporal dynamic to the way songs accumulate narrative meanings as they are interpreted through repeated listens and from conversations with others. Not only does meaning continually accrue, but the interpretation of narrative moves back and forth from specific song text to other songs, to knowledge of cultural forms (art, books, films) and personal experience. Hence, I am arguing that an exploration of intersubjective dialogue and the intercontextual accumulation of meaning provides a richer understanding of the meaning of songs than notions of "subject position" or "personal listening" which tend to emphasize location and place. It also allows for moving away from fixed or static accounts of song texts, towards recognition of the life of songs, the way songs accumulate meaning through time. A sense of this dynamic is suggested in a less scholarly context in the following comments from Bruce Springsteen when replying to an interviewer who asked about the interpretation of his songs, and in particular to the way that the song "Born in the U.S.A" had been appropriated for narrowly patriotic and politically right agendas that had not been foreseen by the songwriter:

Meaning is a communal cocktail. There is no writer who writes something and then has the fascistic ability to dictate how it is perceived, y'know? That doesn't exist. And then you, as the artist, can react to your listener's responses. You can talk about it, you can speak before it, you can play it a different way ... It becomes part of an ongoing conversation. A conversation that is never truly over ... once it is released, it literally is released. It's gone free. And as such, even though you're its creator, you are now part of the community that is discussing, fighting, arguing, enjoying the conversation over its meaning. You may have an ace up your sleeve in that you can go out and play it a certain 
way on another night, but then you are simply adding to that conversation, you are never going to completely define that conversation - no one really can. ${ }^{78}$

The interesting point for me about this quote is not that it highlights the way songs are open to different interpretations (this is by now a commonplace). Instead, it is the way Springsteen acknowledges that the meaning of songs emerge cumulatively, in an unfinished way as part of an intersubjective, intercontextual and "communal" conversation (which does not need to imply a "community" in any united or shared sense of the term). Such "conversations" are typical of how the narrative meanings of songs are understood.

Narratives - the stories we tell about our experiences, observations and imaginings cannot be comprehended and constrained within or by any one text. Hence, my discussion of "I Want To Hold Your Hand" as an example of the difficulty of defining a "non-narrative" popular music text. Songs are produced and perceived within grids of intertextuality and intercontextuality - semiotics chains, networks of social encounters within which interpretations are proposed, debated, accepted or rejected, a dialogue that continues into the future.

I have followed Ricoeur in arguing that we humans narrate our daily triumphs and tribulations through fictions and histories that are both personal and collective. Interpretation and narrative are intersubjective. But, this does not mean that all subjects and their interpretations are equal. The sociology of cultural production provides persuasive evidence of how opportunities are shaped by social environments and institutions, structuring and mediating individual and group abilities to participate in such hermeneutics - whether the strictures of religious orthodoxies, the commercial imperatives of business, or the regulatory regimes of state organizations. Yet, to paraphrase Springsteen, such institutions and forces cannot define or control the conversation. The examples I have chosen to cite in this article are droplets from a pool of countless songs that continually cross, consume and confuse the boundaries between fact and fiction, between the empirical and the imaginative, between documentary and drama, and between reality and its representation.

\section{NOTES}

${ }^{1}$ For just one example of this neglect see the conspicuous absence of song and music in $\mathrm{H}$. Porter Abbott, The Cambridge Introduction to Narrative (Cambridge: Cambridge University Press, 2002).

${ }^{2}$ For overviews see Emma Kafalenos, "Overview of the Music and Narrative Field" in MarieLaure Ryan (ed) Narrative Across Media: the Languages of Storytelling (London: Routledge, 2004), 275-282; and Fred Everett Maus "Narratology, narrativity," Grove Music Online, Oxford Music Online, http://www.oxfordmusiconline.com/subscriber/article/grove/music/40607 [accessed 20 October 2009]. For an influential approach which seeks to extend or overcome the perceived limitations of formal analytical approaches without moving away from a focus on the text see Carolyn Abbate, Unsung Voices: opera and musical narrative in the nineteenth century (Princeton University Press: Princeton NJ, 1991). For a critique of a narrative approach to western art music see Jean-Jacques Nattiez, "Can One Speak of Narrativity in Music?" Journal of the Royal Musical Association, 115 No 2 (1990), 240-257 (translated Katharine Ellis). For a further intervention and contextualization of the above see Fred Everett Maus "Classical Instrumental Music and Narrative" in James Phelan \& Peter J Rabinowitz (eds) A Companion To Narrative Theory (Oxford: Blackwell, 2005), 466-483.

${ }^{3}$ Most notable and influential here is Claudia Gorbman Unheard Melodies, Narrative Film Music (London: BFI, 1988).

4 The application of literary criticism has been notable in approaches to the lyrics of Bob Dylan. See, for example, Aidan Day, Jokerman, Reading the Lyrics of Bob Dylan (Oxford: Blackwell, 1988) and Christopher Ricks, Dylan's Visions of Sin (London: Viking, 2003) 
${ }^{5}$ It is striking how little sustained scholarly attention has been devoted to the song as a form of storytelling. Notable exceptions to this neglect include Simon Frith's brief mention of narrative in his argument about the importance of treating songs and their reception as performances, see Performing Rites, On the Value of Popular Music (Oxford: Oxford University Press, 1996); Jocelyn Neal's study of country music songwriting since the 1980s, "Narrative Paradigms, Musical Signifiers, and Form as Function in Country Music" Music Theory Spectrum, 29 No 1 (2007), 41-72; Serge Lacasse's equally focused and detailed case study of Eminem, "Phonographic Narrative Strategies in Eminem's 'Stan"”' (2007), www.charm.rhul.ac.uk/content/events/s4Lacasse.text.pdf; Robynn Stilwell's study of the use of Phil Collin's "In the Air Tonight" in television and film narratives, "In the Air Tonight: Text, Intertextuality and the Construction of Meaning" Popular Music and Society, 19 No 4 (1995) 67-103.

${ }^{6}$ David Nicholls, "Narrative Theory as an Analytical Tool in the Study of Popular Music Texts," Music \& Letters, 88 No 2 (2007), 297-315.

${ }^{7}$ Nicholls, "Narrative Theory as an Analytical Tool in the Study of Popular Music Texts," 301.

${ }^{8}$ Nicholls, "Narrative Theory as an Analytical Tool in the Study of Popular Music Texts," 302.

Space does not permit an extended engagement with this specific track, but it strikes me that this characteristic quality - an "unvarying melody" - may actually contribute to the narrative tension by offering a moment that appears to be suspended or caught in the present: the ennui of that sensation of "don't you want me?"

${ }^{9}$ Nicholls, "Narrative Theory as an Analytical Tool" 303.

${ }^{10}$ Nicholls, "Narrative Theory as an Analytical Tool" 303.

${ }^{11}$ Nicholls, "Narrative Theory as an Analytical Tool" 301.

12 Various aspects of progressive rock are debated in Kevin Holm-Hudson (ed) Progressive Rock Reconsidered (London: Routledge, 2001).

${ }^{13}$ Lawrence Kramer "Musical Narratology: A Theoretical Outline," Indiana Theory Review, Vol 12, 141-162, (1991) p162.

${ }^{14}$ The use of existing songs as inspiration or models for songwriting is an issue that frequently crops up in Paul Zollo's collection of interviews Songwriters on Songwriting, Fourth Edition, (New York: Da Capo, 2003).

${ }^{15}$ Nicholls, "Narrative Theory as an Analytical Tool" 301

16 Barbara Bradby "She Told Me What to Say': The Beatles and Girl-Group Discourse," Popular Music and Society, 28 No 3, (2005) 359-390; 360 - emphasis in original.

${ }^{17}$ Bradby "She Told Me What to Say" 373.

${ }^{18}$ Bradby "She Told Me What to Say" 377.

${ }^{19}$ Fred Everett Maus "Music as Drama," Music Theory Spectrum, 10, No 1, (1988) 56-73; 65-6

${ }^{20}$ Fred Everett Maus "Narratology, narrativity," 2.

${ }^{21}$ Maus, "Music as Drama," 73.

${ }^{22}$ Walter Everett, The Beatles As Musicians: The Quarry Men Through Rubber Soul (Oxford: Oxford University Press, 2001) 200-01.

${ }^{23}$ Dominic Pedler The Songwriting Secrets of The Beatles (New York and London: Omnibus Press, 2003), 110-112.

${ }^{24}$ Ian MacDonald Revolution in the Head, The Beatles" Records and the Sixties, (London: Fourth Estate, 1994), 76.

${ }^{25}$ Everett, The Beatles As Musicians, 202.

${ }^{26}$ Cited in MacDonald, Revolution in the Head, 78. See also Howard Sounes, Down the Highway, The Life of Bob Dylan, (London: Black Swan, 2001), 198.

27 For further discussion of this point see various sections of Wilfrid Mellers Twilight of the Gods, The Beatles in Retrospect (London: Faber and Faber, 1973) and Keith Negus Bob Dylan (London: Equinox, 2008), 75. 
28 Nicholls "Narrative Theory as an Analytical Tool" 297

29 See, for example, Tom Perchard Lee Morgan: His Life, Music and Culture (London: Equinox, 2006).

${ }^{30}$ Eric F Clarke "Subject-Position and the Specification of Invariants in Music by Frank Zappa and P.J.Harvey" Music Analysis 18 No 3 (1999) 347-374. Clarke draws from its use in the study of film. It is debatable whether the political imperatives that informed the development of the concept in Marxism were retained in film studies. The link to ideological critique and political praxis has almost disappeared on its journey into music analysis.

${ }^{31}$ Clarke "Subject-Position and the Specification of Invariants in Music by Frank Zappa and P.J.Harvey," 354

${ }^{32}$ Clarke "Subject-Position and the Specification of Invariants in Music by Frank Zappa and P.J.Harvey," 371

${ }^{33}$ Nicola Dibben "Pulp, Pornography and Spectatorship: Subject Matter and Subject Position in Pulp's This is Hardcore" Journal of the Royal Musical Association 126 No 1 (2001) 83-106.

34 Tia DeNora Music in Everyday Life (Cambridge: Cambridge University Press, 2000).

${ }^{35}$ Eric F Clarke Ways of Listening, An Ecological Approach to the Perception of Musical Meaning (Oxford University Press, 2005) 124

${ }^{36}$ Tia DeNora, After Adorno, Rethinking Music Sociology (Cambridge: Cambridge University Press).

${ }^{37}$ DeNora, After Adorno 92

${ }^{38}$ DeNora, After Adorno 154

${ }^{39}$ Chris Kennett "Is Anybody Listening?" in A Moore (ed) Analyzing Popular Music

(Cambridge, Cambridge University Press, 2003) 207-8

${ }^{40}$ Chris Kennett “A Tribe Called Chris: Pop Music Analysis as Idioethnomusicology,” The Open Space Magazine, Vol 10, (2008) 8-19, 13.

${ }^{41}$ Kennett "Is Anybody Listening?"

${ }^{42}$ Kennett "A Tribe Called Chris," 17

${ }^{43}$ Kennett "A Tribe Called Chris," 17

44 "Empathy" being a key concept in Edmund Husserl's development of the notion of "intersubjectivity."

45 A similar idea to this notion of shared understanding is being explored and developed by Nick Reyland through his "listener-response theory" in "Listening for the plot: towards a readerresponse theory of musical narrativity" Lancaster Institute for Contemporary Arts Research Seminar, 8 June 2010.

${ }^{46}$ Kennett "A Tribe Called Chris," 17

47 See Ian Maxwell "The Curse of Fandom: Insiders, Outsiders and Ethnography" in David Hesmondhalgh \& Keith Negus (eds) Popular Music Studies (London: Arnold, 2002), 103-116. See also Simon Frith Performing Rites: On the Value of Popular Music (Oxford, Oxford University Press 1996).

48 Abbott, The Cambridge Introduction to Narrative 66.

${ }^{49}$ William Empson, Seven Types of Ambiguity, A Study of Its Effects in English Verse (London: Chatto \& Windus, 1930, 1947, 1953). 1, x.

${ }^{50}$ Empson, Seven Types of Ambiguity, 3

${ }^{51}$ Umberto Eco The Limits of Interpretatation (Bloomington and Indianapolis: Indiana University Press 1990), p6

52 See, for example, www.kissthisguy.com - The Archive of Misheard Lyrics.

53 See Umberto Eco, Richard Rorty, Jonathan Culler, Christine Brooke-Rose Interpretation and Overinterpretation (Cambridge: Cambridge University Press 1992).

${ }^{54}$ See Paul Ricoeur Time and Narrative Vol $1-3$ transl. Kathleen McLaughlin and David Pellauer (Chicago: University of Chicago, 1984-88); Paul Ricoeur "Narrated Time" (1984) in 
Mario J Valdés, A Ricoeur Reader: Reflection and Imagination (Hemel Hempstead: Harvester Wheatsheaf, 1991). See also Richard Kearney "Narrative imagination: between ethics and poetics" in Richard Kearney (ed) Paul Ricoeur, The Hermeneutics of Action (London: Sage, 1996).

55 Mara Rainwater "Refiguring Ricoeur: narrative force and communicative ethics" in Richard Kearney (ed) Paul Ricoeur, The Hermeneutics of Action (London: Sage, 1996) 107.

56 David Rasmussen "Rethinking Subjectivity: Narrative Identity and the Self" in Richard Kearney (ed) Paul Ricoeur, The Hermeneutics of Action (London: Sage, 1996) 160.

${ }^{57}$ Paul Ricoeur "Can Fictional Narratives be True?" Analecta Husserliana XIV (1983) 3-19; 4 , 14,3 .

58 Nick Crossley Intersubjectivity, The Fabric of Social Becoming (Sage, London, 1996) 173-4.

59 David Bloome, Marlene Beierle, Margaret Grigorenko and Susan Goldman "Learning over time: Uses of intercontextuality, collective memories, and classroom chronotopes in the construction of learning opportunities in a ninth-grade language arts classroom" Language and Education 23 No 4 (2009) 313-334; 314.

${ }^{60}$ Those unfamiliar with this song can readily access the lyrics at http://www.steelydan.com/lyrroyalscam.html\#track1

${ }^{61}$ Walter Everett "A Royal Scam: The Abstruse and Ironic Bop-Rock Harmony of Steely Dan," Music Theory Spectrum, Vol 26 (2004) 201-35; 201.

${ }^{62}$ Don Breithaupt Aja (New York: Continuum, 2007).

${ }^{63}$ Cited in Bruce Pollock and John Stix 'Steely Dan, Introduction" 2-3 Steely Dan Complete, (Miami: Universal Music Publishing, Warner Brothers, 1995), 2. See also Ben Williams "Influences: Donald Fagen" New York Magazine, 19 March 2006 http://nymag.com/arts/popmusic/profiles/16453/ accessed 4 November 2011.

64 For an extended discussion of this point see Don Breithaupt Aja (New York: Continuum, 2007).

65 Jocelyn Neal highlights the structural principles of songwriting in country music; repeated choruses in which the lyrical text does not change and "must continue to be relevant after the song's plot has progressed through additional verses" "Narrative Paradigms, Musical Signifiers, and Form as Function in Country Music" 45.

${ }^{66}$ Max Bell, "Steely Dan," New Musical Express, originally 13 August 1977, retrieved from www.rocksbackpages.com, article ID 11904, 15 December 2009, 5.

67 John Markert "Sing a Song of Drug Use-Abuse: Four Decades of Drug Lyrics in Popular Music - From the Sixties through the Nineties" Sociological Inquiry, 71 No 2 (2001) 194-220.

${ }^{68}$ Becker's and Fagen's songs use harmonies and voicing, and transitions to chords and keys that would be unexpected in conventional rock sequences. This may destabilize or broaden the tone, inflecting lyrics with an ominous or disconcerting mood. For further discussion see Everett "A Royal Scam: The Abstruse and Ironic Bop-Rock Harmony of Steely Dan" and Breithaupt Aja.

${ }^{69}$ See for example http://www.songmeanings.net and http://www.songfacts.com.

70 Robert J Toth “A World of My Own,” March 2000, www.steelydan.com/toth.html accessed 8 February 2010.

${ }^{71}$ Paul Clements has written of his own enthusiasm for Steely Dan's "outsider hip" and "cult" status: "In my own case of adolescence in a small town in England, this music alongside a range of other less mainstream popular music forms represented creative aspiration (especially a career as a jazz or rock musician) ... Steely Dan ... represented a complex and sophisticated popular music championed in the main by a predominantly male grouping which identified with the jazz/beat lifestyle." See "Cultural legitimacy or "outsider hip"?: Representational Ambiguity and the Significance of Steely Dan” Leisure Studies 28 No 2 (2009), 189-206; 196.

72 Toth "A World of My Own" np. 
73 Sheila Whitleley, The Space Between the Notes: Rock and the Counter-Culture (London: Routledge, 1992).

74 Jay Stevens Storming Heaven, LSD and the American Dream (New York: Grove Press, 1987), 311.

75 Stevens Storming Heaven, LSD and the American Dream 313

${ }^{76}$ Martin A Lee \& Bruce Shlain Acid Dreams, The Complete Social History of LSD: The CIA, the Sixties and Beyond, (New York: Grove Press, 1992), 146.

${ }^{77}$ Christopher Gair The American Counterculture (Edinburgh: Edinburgh University Press, 2007), 134.

${ }^{78}$ Keith Cameron "Leader of the Pack" Mojo 201 (August 2010), 76-86; 84. 